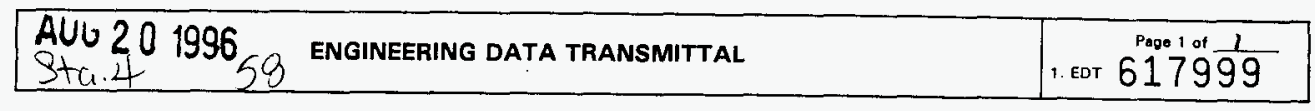

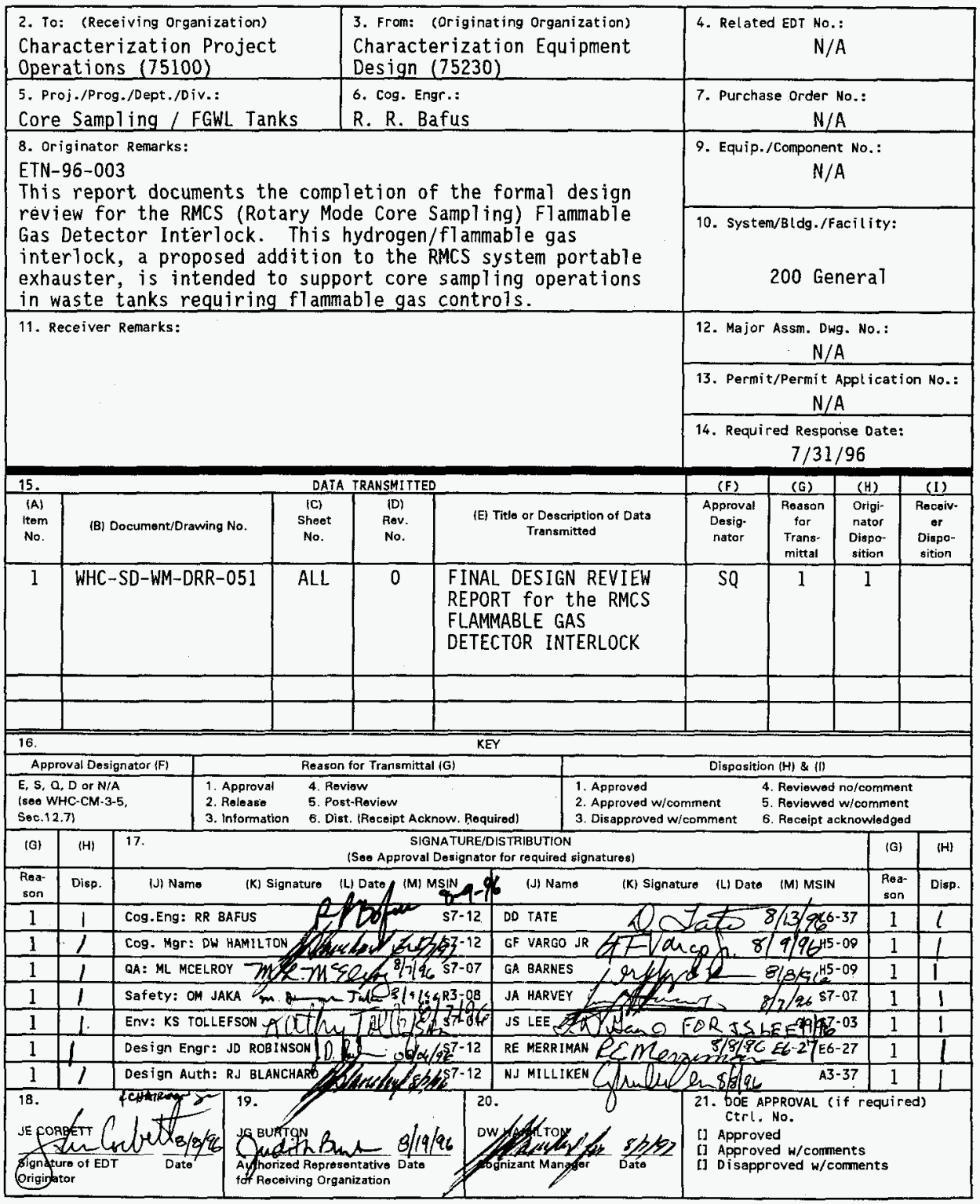




\title{
FINAL DESIGN REVIEW REPORT for the RMCS FLAMMABLE GAS DETECTOR INTERLOCK
}

\author{
J. E. Corbett \\ Westinghouse Hanford Company, Richland, WA 99352 \\ U.S. Department of Energy Contract DE-AC06-87RL10930
EDT/ECN: 617999
UC: 2030
Org Code: W75230
Charge Code: N4HBB
B\&R Code: 35 EW 31207 Total Pages: 37

Key Words: Exhauster, Flammable Gas Detector, FGD, Hydrogen Interlock, Core Sampling, Flammable Gas Watch List, Rotary Mode Core Sampling, RMCS, Core Sample Truck, Preliminary Design Review, 100\% Design Review, Design Review Report

Abstract: This report documents the completion of the formal design review for the RMCS (Rotary Mode Core Sampling) flammable gas detector interlock. This hydrogen/flammable gas interlock, a proposed addition to the RMCS system portable exhauster, is intended to support core sampling operations in waste tanks requiring flammable gas controls. The objective of this review was to approve new drawings at the $100 \%$ design completion state. The conclusion reached by the review committee was that the design was acceptable and efforts should continue toward fabrication and delivery.

TRRDEMARK DISCLAIMER. Reference herein to any specific commercial product, process, or service by trade name, trademark, manufacturer, or otherwise, does not necessarily constitute or imply its endorsement, recomnendation, or favoring by the United States Government or any agency thereof or its contractors or subcontractors.

Printed in the United States of America. To obtain copies of this document, contact: WHC/BCS

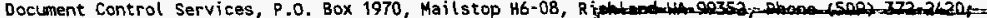
Fax (509) $376-4989$.
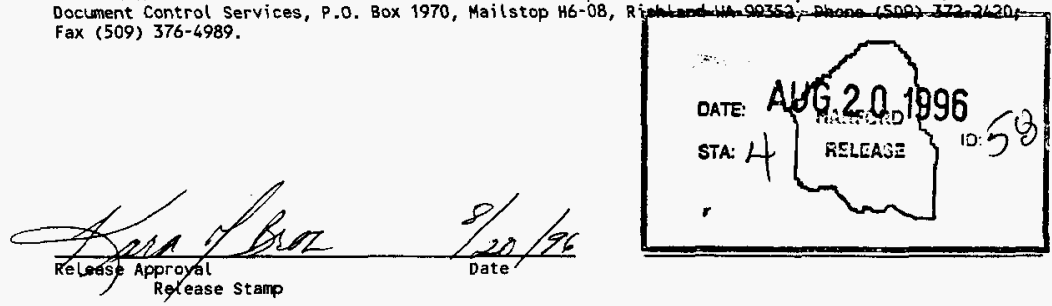

Approved for Public Release 
WHC-SD-WM-DRR-051, Rev. 0

FINAL DESIGN REVIEW REPORT

for the

RMCS FLAMMABLE GAS DETECTOR INTERLOCK

\author{
Issued by: \\ J. E. Corbett, Senior Engineer \\ Tank Waste Remediation System \\ Characterization Project
}


WHC-SD-WM-DRR-051, Rev. 0

\section{TABLE OF CONTENTS}

$1.0 \mathrm{SCOPE} \ldots \ldots \ldots \ldots \ldots \ldots \ldots$

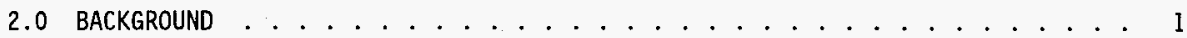

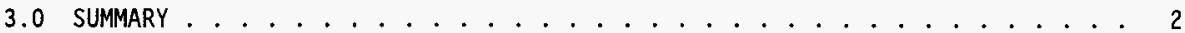

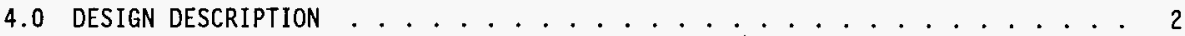

5.0 DEVELOPMENT CONTROL . . . . . . . . . . . . . . . . . . . 3

6.0 LISTING OF REVIEW MATERIALS . . . . . . . . . . . . . . . . . . . 4

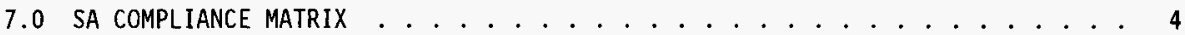

8.0 DESIGN REVIEW CHECKLIST . . . . . . . . . . . . . . . . . 6

9.0 REVIEW COMMENT RECORDS . . . . . . . . . . . . . . . . . . 6

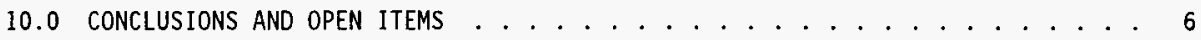

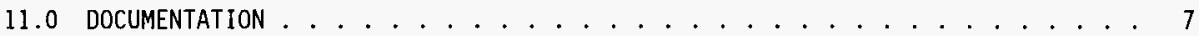

\section{ACRONYMS}

ATP acceptance test procedure

CED Characterization Equipment Design

CFR Code of Federal Regutations

CPO Characterization Project Operations

DRR design review report

ECN engineering change order

EP

FDC

FGD

FGWL

HEPA

OTP

ppm

RCR

RMCS

SMC

WHC

Engineering Practices

functional design criteria

flammable gas detector

flammable gas watch list

high efficiency particulate air (filter)

operability test procedure

parts per million

review comment record

rotary mode core sampling

Sierra Monitor Corporation

Westinghouse Hanford Company 


\section{RMCS Flammable Gas Detector Interlock, Final Design Review}

\subsection{SCOPE}

This report documents the completion of the formal design review for the RMCS (Rotary Mode Core Sampling) Flammable Gas Detector Interlock. During the preliminary design stage of this equipment, the detection capability was limited to hydrogen, and was therefore referred to as the Hydrogen Interlock. Because the interlock was initially associated only with the RMCS exhauster, it is also referred to as the Exhauster Interlock or the Flammable Gas Tank Exhauster Interlock. The approved safety assessment (WHC-SD-WM-SAD-035) refers to this equipment as the flammable gas detector (FGD) or the flammable gas detection system. For the purposes of clarity and brevity, this report will hereafter refer to the system as the "FGD interlock."

The FGD interlock design review included preliminary and final review of new drawings, considered to be at the $100 \%$ design completion state. These drawings are listed in section 6.0 . This document and the formal design review are in support of design modifications to the core sampling systems used by Characterization Project Operations (CPO). These modifications, including the addition of the FGD Interlock, are required to expand the scope of core sampling to include Flammable Gas Watchlist (FGWL) tanks, as well as any other tanks with flammable gas controls. The objective of this review was to provide a forma $i$ design verification consisting of a systematic overall review and evaluation of the FGD Interlock. Design verification is performed to insure equipment function, personnel safety, and compliance with WHC-CM-61, Standard Engineering Practices, section 2.2.4, and the quality assurance requirements of 10 CFR 830.120 . Acceptance of the design is required prior to operational use on any waste tanks requiring flammable gas controls. RMCS exhauster and core sample truck modifications are evaluated in separate design reviews and are not part of this report.

\subsection{BACKGROUND}

The Rotary Mode Core Sampling (RMCS) systems were designed for initial deployment to FeCN tanks, with later modifications intended to allow for deployment to Flammable Gas Watch List (FGWL) tanks. These modifications include the addition of flammable gas detection and automatic shutdown features, using equipment designed for use in flammable atmospheres. A functional design criteria (WHC-SD-WM-FDC-045) was used to establish the basis criteria for the FGD Interlock. 


\subsection{SUMMARY}

The design review committee was selected in accordance with EP 4.1 and is documented in Section 11.0 of this report. A preliminary design review was performed at the $50 \%$ level. This portion of the formal design review was completed on January $4 \mathrm{th}, 1996$, and is documented in WHC-SD-WM-DRR-050.

The kickoff meeting for the $100 \%$ level design review was held on January 10 th, 1996. This meeting served as the first of two final design review briefings. Updated design information, including the draft software design description (WHC-SD-WM-CSSD-019) and the design drawings, was provided at this briefing. The second final design review briefing was held on February 28th, where the new spool piece design, incorporating combustible gas detection, was described. Meeting minutes for these briefings are attachments to Section 11.0 of this report.

The final design review close-out meeting was delayed in order to accommodated changes made to the SA, WHC-SD-WM-SAD-035, A Safety Assessment of Rotary Mode Core Sampling in Flammable Gas Single Shell Tanks, and to complete key development testing. The meeting was held on June 6th. Of the four review comment records (RCR's) submitted for the final design review, three were clased out prior to the meeting, and the last one was closed out immediately after the meeting. For a complete listing of RCR's, see section 9.0 of this report. A listing of open items can be found in section 10.0. The design drawings were essentially complete. Incorporation of redines and drawing check will be accomplished prior to release. A final drawing review will be performed by the design review committee, and is listed as an open action item in Section 10.0 of this report. Meeting minutes for the close-out meetings, and the completed design review checklist, are attachments to Section 11.0 of this report.

After the completion of the close out meetings, the conclusion reached by the review committee was that the design of the FGD Interlock was acceptable and efforts should continue toward fabrication and delivery.

\subsection{DESIGN DESCRIPTION}

The FGD Interlock consists of four primary components: a spool piece with gas sensors to obtain gas samples from the exhaust stream; two identical, separate, electronic packages mounted on wheeled carts; and a power distribution skid with redundant shut-off contractors. The system is powered by the same source as the exhauster, through the RMCS electrical power distribution trailer. The flexible duct from the waste tank is attached to the spool piece which is bolted directed to the exhauster heater. The ventilation stream passes through the spool piece and into the exhauster. Attached to the spool piece are two separate flammable gas sensors; a Whittaker hydrogen detector cell and a Sierra Monitor Corporation (SMC) combustible gas detector.

The purpose of the gas sensors on the spool piece is to provide safety shutdown signals for both flammability and toxic hazards during core sampling operations. Upon detection of out-of-tolerance conditions, the interlock will alarm and initiate a shutdown of the RMCS drill rig. 
The Whittaker Cell, an electrochemical cell with a membrane placed between the sample gas and the active element, is very selective for hydrogen and responds directly to the partial pressure of hydrogen on the other side of the membrane. Significant experience with Whittaker has shown them to be stable and reliable in the tank farm environment.

The SMC combustible gas sensor uses a catalyst to "burn" the gas and detects the resulting heat release. To increase sensitivity and decrease drift, the heat detection is done by comparing the temperature of a reference (uncatalyzed bead) to that of a signal (catalyzed) bead. The beads are imbedded in a sintered metal housing which prevents the combustion energy from igniting a flammable mixture. It has the advantage of responding to both ammonia and hydrogen. The SMC detector has not been used extensively in the tank farm environment.

Sample flow to each instrument is provided by a pressure differential within the spool piece--no sample pumps are used. Signals from the flammable gas instruments are processed by redundant programmable logic controllers. If flammable gas concentrations exceed $5000 \mathrm{ppm}$, the rate of change in flammable gas concentrations greater than $100 \mathrm{ppm} / \mathrm{sec}$ for 10 seconds, or the tank pressure increased more than two inches water gage in six minutes, the exhauster will remain operational and the truck will be shut down. The exhauster internal shutdown alarms (low and high flow, and HEPA filter differential pressure) are unaffected by the FGD Interlock.

If FGD Inter lock power is lost, or tank pressure falls to less than -3 inches water gauge, electric power to the exhauster is terminated. Exhauster shutdown will automatically result in core sampling drill truck shutdown via the existing connection.

Further details and controls are described in the SA.

\subsection{DEVELOPMENT CONTROL.}

The drawing configuration control methodology for the design and fabrication of the FGD Interlock is described in the JD Robinson memo attached to section 11.0 of this report. The configuration control method chosen follows the requirements of EP-2.4, Development Control Requirements as contained in WHCCM-6-1, Standard Enqineering Practices. In response to an action item assigned during the design review briefing, the engineering task plan, WHC-SDWM-ETP-165, was changed to include the configuration management requirements. 


\subsection{LISTING OF REVIEW MATERIALS}

The following new drawings were reviewed and approved for fabrication, per the above development control requirements, as part of the formal design review:

\begin{tabular}{||l|l||}
\hline DRAWING \# & \multicolumn{1}{|c||}{ TITLE } \\
\hline DWG-100519 & FLAMMABLE GAS TANK EXHAUSTER INTERLOCK ELEM DIAGRAM (2205) \\
\hline DWG-100520 & FLAMMABLE GAS TANK EXHAUSTER INTERLOCK ELEM DIAGRAM (2206) \\
\hline DWG-100521 & $\begin{array}{l}\text { FLAMMABLE GAS TANK EXHAUSTER INTERLOCK CART'S } 2205 / 2206 \\
\text { ASSY'S }\end{array}$ \\
\hline DWG-100522 & FLAMMABLE GAS TANK EXH. CABLE ARRANGMENT AND ASSEMBLIES \\
\hline DWG-100523 & SAMPLER SPOOL INSTALLATION \\
\hline DWG-100524 & SAMPLER SPOOL ASSEMBLY \\
\hline DWG-100530 & FLAMMABLE GAS TANK EXHAUSTER INTERLOCK PWR DISTRIBUTION DIAG \\
\hline DWG-100531 & INTERCONNECTION DIAGRAM EXHAUSTER CART 2205 \\
\hline DWG-100532 & INTERCONNECTION DIAGRAM EXHAUSTER CART 2206 \\
\hline
\end{tabular}

\subsection{SA COMPLIANCE MATRIX}

The table on the following page was used as a tool for determining which safety requirements from the SA (WHC-SD-WM-SAD-035) are design criteria for the design modifications being made to RMCS equipment. Each credited design safety feature listed in the $S A$ is shown on the left side of the table. The corresponding implementing document( $s$, shown on the right side of the table, is generally the ECN or new drawing which incorporates the safety feature into the RMCS design for flammable gas tanks. In many cases, where the implementing document is shown as "existing," the design feature was incorporated in the existing design for the RMCS system, and no modification was required. The FGD Interlock is 1 isted as item \#45, and is incorporated into the RMCS system by the installation drawing H-14-100523. The remaining items in the table apply to components of the RMCS system, and are not applicable to this design review. 


\begin{tabular}{|c|c|c|}
\hline$\#$ & CHAPTER 6 - SAFETY FEATURES & IMPLEMENTING DOCUMENT \\
\hline 1 & Material compatibility (On-site) & ECN 631116,631126, H-2-590142, memo 75230-96-001, rev. 2 \\
\hline 2 & Spark-resistant tools (NA) & Administrative Control (Procedure) \\
\hline 3 & Grounding and bonding (NA) & ECN 626742 and approved grounding procedure \\
\hline 4 & Radiological controls (NA) & Existing - Exhauster housing $<100 \mathrm{mR}$ on contact \\
\hline 5 & Riser sleeve (Off-site) & ECN 628706 (H-2-690128, H-2-690131) \\
\hline 6 & Drill string spray washer (NA) & Existing \\
\hline 7 & Frisbee/DS interface lubricant (NA) & Existing \\
\hline 8 & Pneumatic foot elamp (Off-site) & In work \\
\hline 9 & Drill bit configuration \& mat'l (Ofl-site) & Existing - certified by USBM testing \\
\hline 10 & Drill centering spike (NA) & Existing \\
\hline 11 & Chevron seal between drill bit \& sampler (NA) & Existing \\
\hline 12 & Core sampler and drill string components (Off-site) & $\#$ TBD \\
\hline 13 & Sniffing ports (NA) & Existing ( $\mathrm{H}-2-826513$ ) \\
\hline 14 & Change-out assembly (NA) & Existing \\
\hline 15 & Cable spray washer (NA) & Existing \\
\hline 16 & Purge flow limitation (Off-site) & Existing \\
\hline 17 & Original speed limitation (Off-site) & Existing \\
\hline 18 & Downforce limitation (Off-site) & Existing \\
\hline 19 & Drill string penetration rate (Off-site) & ECN 626740 \\
\hline 20 & Hydraulic bottom detector (Off-site) & Existing \\
\hline 21 & Walkdown function (Off-site) & Existing \\
\hline 22 & Hydrostatic head (NA) & Existing \\
\hline 23 & Truck position (Off-site) & Existing \\
\hline 24 & Stabilizing jacks (NA) & Existing \\
\hline 25 & Quill rod adapter (Off-site) & ECN 631126 \\
\hline 26 & Grapple hoist assembly (Off-site) & ECN 628712,626742 \\
\hline 27 & Grapple (sample actuator) (Off-site) & Existing \\
\hline 28 & Grapple insertion (NA) & Existing \\
\hline 29 & Grapple hoist cable tension (NA) & Existing \\
\hline 30 & Shielded receiver assembly (Off-site) & ECN $626742,628707,628713$ \\
\hline 31 & SR tube (NA) & Existing \\
\hline 32 & SR view port (NA) & Existing \\
\hline 33 & SR hoist cable tension (NA) & Existing \\
\hline 34 & Remote latch unit (Off-site) & H-2-690142, ECN 628708, 628711, 628714, 628715 \\
\hline 35 & RLU insertion (NA) & Existing \\
\hline 36 & RLU position indicator (NA) & Existing \\
\hline 37 & Exhauster Operation (Off-site) & ECN 632390 \\
\hline 38 & Exhauster intrinsic safety (Off-site) & ECN 628744 \\
\hline 39 & Exhauster PLC & ECN 632390 \\
\hline 40 & Exhauster duct (Off-site) & ECN 628744 \\
\hline 41 & Exhauster heater (Otf-site) & $\mathrm{H}-14-100739$ \\
\hline 42 & Exhauster fan and motor assembly (Off-site) & ECN 628744 \\
\hline 43 & Inlet breather stack (Off-site) & $H-14-100742$ \\
\hline 44 & Tank pressure detection (Off-site) & Existing, and $\mathrm{H}-14-100521$ \\
\hline 45 & Flammable gas detector (Off-site) & $\mathrm{H}-14-100523$ \\
\hline 46 & X-ray containment (NA) & Vi File, Internal memo 75230-96-006 \\
\hline 47 & DS nitrogen purge supply (Off-site) & Existing \\
\hline 48 & Nitrogen hydrostatic head supply (NA) & Existing \\
\hline 49 & Riser sleeve nitrogen purge supply (NA) & H-2-690128, ECN 628706, ECN 626741 \\
\hline 50 & Unique connections (NA) & $\mathrm{H}-2-690128, \mathrm{ECN} 630017$ \\
\hline 51 & Truck PLC (OHf-site) & ECN 623775 \\
\hline 52 & Audible and visual annunciation (NA) & ECN 623775 \\
\hline 53 & Shutdown interlock (Off-site) & Existing \\
\hline
\end{tabular}




\subsection{DESIGN REVIEW CHECKLIST}

Formal design reviews, as described in WHC-CM-6-1, Standard Engineering Practices, are required to use a design review checklist that has been customized for the review. The checkilist developed by the design review committee for this review is listed as an attachment to section 11.0 of this report. The checklist was satisfactorily completed, and all open items from the checklist are discussed in section 10.0 of this report.

\subsection{REVIEW COMMENT RECORDS}

The following table is a listing of all RCR's received during the design review. AlI RCR's were dispositioned and signed off as closed. A copy of each dispositioned RCR is included as an attachment to Section 11.0 of this report.

\section{RCR STATUS 6/6/96 (COB)}

Final Design Review, FGD Interlock

\begin{tabular}{|c|c|c|}
\hline REVIEWER/DATE/NUMBER & RESP. ENGINEER & RCR STATUS \\
\hline Krugsrud/0122/1 & George vargo & Closed $4 / 24 / 96$ \\
\hline Merriman $/ 0130 / 1$ & George Vargo & Closed $6 / 6 / 96$ \\
\hline MartelL/0312/1 & Jim Robinson & Closed $3 / 12 / 96$ \\
\hline Krugsrud/0312/1 & Jim Robinson & $C$ losed $4 / 24 / 96$ \\
\hline
\end{tabular}

\subsection{CONCLUSIONS AND OPEN ITEMS}

With the approval of this report, the formal design review for the FGD Interlock is completed. The following open items were noted during the design review. These items are scheduled to be completed as part of the normal course of business and are not action items for the design review committee. Therefore, these items are NOT considered to be "open action items" as described in WHC-CM-6-1, EP-4.1, paragraph 2.3.3.2, "Documentation of Action Item Completion."

OPEN ITEM: ATP/OTP testing to demonstrate requirements/operability

OPEN ITEM: operation and maintenance procedures revised to reflect modifications

The following action items were noted during the design review. These "open action items" will be closed in accordance with the requirements described in WHC-CM-6-1, EP-4.1

ACTION ITEM: Release of design drawings (1 isted in section 6.0); assigned to CED.

The conclusion reached by the design review committee is that the design of the FGD Interlock is acceptable. There are no further action items for the review committee. 


\subsection{DOCUMENTATION}

The following items are provided as attachments to this report:

1. Listing of design review committee members

2. Design Review Checklist

3. Copies of RCR's

4. Meeting Minutes (includes JD Robinson memo of $1 / 15 / 96$ )

Review copies of all drawings provided to committee members for final review are available in the design review file. All released documentation referenced in the report will be available using the controlled document number located in the text where the document is cited. 


\section{ATTACHMENT 1 \\ Design Review Committee Members}

NOTE:

This attachment established the review committee during the prliminary design review.

Changes made during the final review are documented in the meeting minutes (Attachment 4 ). 
From: Characterization Equipment Design

$75230-95-030$

Phone: $373-1248$ 57-12

Date: $\quad$ October 2, 1995

Subject: CHARACTERIZATION PROGRAM-- FORHAL DESIGN REVIEW BRIEFING FOR THE HYDROGEN INTERLOCK, ROTARY MODE CORE SAMPLING SYSTEM PORTABLE EXHAUSTER

To: Distribution

$\begin{array}{ll}\text { cc: G. A. Barnes } & H 5-09 \\ \text { R. J. Blanchard } & 57-12 \\ \text { L. E. Borneman } & R I-52 \\ \text { J. E. Corbett } & 57-12 \\ \text { D. W. Hamilton } & 57-12 \\ \text { J. A. Harvey } & \$ 7-07 \\ \text { H. E. Huda } & 57-07 \\ \text { L. S. Krogsrud } & \text { R3-08 } \\ \text { J. S. Lee } & 57-08\end{array}$

M. L. McElroy

R. E. Merriman

N. 3. Milliken

R. E. Raymond

J. D. Robinson

J. S. Schofield

E. K. Straalsund

G. F. Vargo Jr

E. J. Waldo

RJ3: File LB
57-07

[6-27

44-65

$57-12$

$57-12$

$57-12$

ᄂ5-37

H5-09

$57-12$

A design review briefing meeting for the Hydrogen Interlock - Rotary Mode Core Sampling System Portable Exhauster will be held on October 4, 1995 (Kednesday), starting at 1:00 p.m. at the 2750E building, room A229. This meeting wili initiate the formal design review for the Hyorogen Interlock $50 \%$ design review state. The Design Review Committee will receive a design review package, Review Cominent Record forms (RCR), and the review checkl ist to record their comnents prior to the subsequent design review meeting. The RCR forms either hard copy or electronic mail forms are to be returned, with comment, to John Corbett or Jim Robinson by October 12, 1995, for compilation and resolution prior to the design review meeting.

The design review meeting is to be held october 17, 1995, at $2750 \mathrm{E}$, room A229. At this meeting each reviewers comments will be discussed to determine if they have been resolved to the reviewer's satisfaction and/or if additional action is required.

The purpose of this review is to determine the technical adequacy of the design based on the Functional Design Requirements document, WHC-SD-WM-FDC045, Revision 0.

The Design Review Committee members and their primary areas of responsibility are listed below. The chairmen was selected by the Characterization Equipment Design Manager, D. W. Hamilton. The committee members were selected by the manager Characterization Equipment Design and epproved by the chairman. 
Page 2

October 2, 1995

\title{
DESIGH REVIEY COMMITTEE
}

R. J. (Roy) Blanchard

J. E. (John) Corbett

G. A. (Geoff) Barnes

L. E. (Lucinda) Bornemann

J. A. (Jerry) Harvey

M.. E. (Huda) Huda (ALTERNATE)

L. S. (Steve) Krogsrud

J. S. (Jim) Lee

M. L. (Mike) MeElroy

R. E. (Ray) Merriman

N. J. (Nancy) Milliken

J. O. (Jim) Robinson

E. K. (Eric) Straalsund

G. F. (George) Vargo Jr.

E. J. (Eric) Waldo

\author{
Design Review Chairman \\ Design Review Secretary \\ Mechanical Engineering \\ Environmental Engineering \\ Industrial Safety \\ Industrial Safety \\ Nuclear Engineering \\ Characterization Operations/Facilities \\ Quality Assurance \\ Electrical Engineering \\ Safety Analysis \\ Cognizant Design Engineer \\ Electrical Instrumentation \\ Cognizant Electrical Design Engineer \\ Interfacing System/Customer Rep. Design
}

J. Blanchard, Senior Principal Engineer

Design Review Chairman

Characterization Equipment Design

concurrence: T. W. Hamilton, Mahager

Characterization Equipment Design

tla 
WHC-SD-WM-DRR-051, ReV. 0

Page A2-1

ATTACHMENT 2

Design Review Checklist 
FORMAL DESIGN REVIEW CHECKLIST RMCS Hydrogen Interlock Exhauster

Document(s) Reviewed:

Drawings \#100519-100524 and 100530-100532 Software Desian Description (1/8/96 Draft) WHC-SD-WM-DRR-050

\begin{tabular}{|c|c|c|c|c|c|}
\hline Item & Review Consideration & Yes & No & NA & Remarks \\
\hline 1 & $\begin{array}{l}\text { Have assumptions necessary to perform the } \\
\text { design task been adequately described and } \\
\text { are they reasonable? Where necessary. } \\
\text { have assumptions been identified for } \\
\text { reverification when the design task has } \\
\text { been completed? }\end{array}$ & $x$ & & & \\
\hline 2 & $\begin{array}{l}\text { Have the appropriate Quality Assurance } \\
\text { requirements been specified? }\end{array}$ & $x$ & & & \\
\hline 3 & Were sources of information identified? & $x$ & & & \\
\hline 4 & $\begin{array}{l}\text { Does the design meet the established } \\
\text { requirements or design criteria? }\end{array}$ & $x$ & & & $\begin{array}{l}\text { Will be demonstrated in } \\
\text { ATP }\end{array}$ \\
\hline 5 & $\begin{array}{l}\text { Does the design meet established } \\
\text { requirements for associated system } \\
\text { physical and functional. interfaces? }\end{array}$ & $x$ & & & . \\
\hline 6 & $\begin{array}{l}\text { Have the interface requirements with site } \\
\text { construction drawings been clearly } \\
\text { specified and are they achievable? }\end{array}$ & $x$ & & & \\
\hline 7 & Are there any interface problens? & & $x$ & & \\
\hline 8 & $\begin{array}{l}\text { Has appropriate consideration been given } \\
\text { to use of standardized parts. materials } \\
\text { and processes. and have engineering } \\
\text { standards and criteria been specified } \\
\text { properly in the design? }\end{array}$ & $x$ & & & \\
\hline 9 & $\begin{array}{l}\text { Does the design represent the simplest } \\
\text { design consistent with functional } \\
\text { requirements and expected service } \\
\text { conditions? }\end{array}$ & $x$ & & & \\
\hline 10 & $\begin{array}{l}\text { Can the equipment be readily } \\
\text { assembled/disassembied as designed? }\end{array}$ & $x$ & & & \\
\hline 11 & $\begin{array}{l}\text { Does the design minimize overall cost to } \\
\text { the extent practicabie? }\end{array}$ & $x$ & & & \\
\hline 12 & $\begin{array}{l}\text { Has the cost estimate been verified by an } \\
\text { independent reviewer? }\end{array}$ & & & $x$ & Not required \\
\hline 13 & $\begin{array}{l}\text { Are the specified materials compatible } \\
\text { with each other and the environmental } \\
\text { conditions to which the material will be } \\
\text { exposed? }\end{array}$ & $x$ & & & \\
\hline 14 & $\begin{array}{l}\text { Are the applicable codes, standards and } \\
\text { requirements, including revisions, } \\
\text { properly identified and are their design } \\
\text { requirements provided for? }\end{array}$ & $x$ & & & \\
\hline 15 & $\begin{array}{l}\text { Have modifications to commercial grade } \\
\text { items and any associated verification } \\
\text { operations or tests been appropriately } \\
\text { documented? }\end{array}$ & $x$ & & & \\
\hline 16 & $\begin{array}{l}\text { Have qualified and certified parts been } \\
\text { specified? }\end{array}$ & $x$ & & & $\cdot$ \\
\hline 17 & $\begin{array}{l}\text { Have available data on similar designs } \\
\text { been used? }\end{array}$ & & & $x$ & No similar designs used \\
\hline
\end{tabular}



requi rements?

a. Stresses are within design imits?

b. Derating is used?

c. Steady-state and transient conditions?

d. Have actual and "worst case" condition stresses been considered rather than nominal average stresses? environmental conditions?

a. Temperature (steady-state and transient)

b. Flow (steady-state and transient) including induced vibration

c. Pressure (steady-state and transient)

d. Seismic/natural phenomena

e. Nuclear radiation

Is the design producible by conventional means?

Do manufacturing. processing, and fabrication procedures minimize stress corrosion and fatigue? resistant to the following as applicable:

a. Moisture

b. Oxygen

c. Acids

d. Salts

e. Radiation

Do the clearances and tolerances take into account the effects of age and wear? $X$

Are mechanical tolerances within the limits of normal shop practice?

Are assembly clearances adequate? Have allowable leakages been specified? where required?

Does the design avoid any materials unproven for use in the anticipated environment? effects?

Has the design appropriately considered maintenance, operation and reliability. including maintenance procedures and techniques, unique maintenance requirements and frequencies?

NOTE: performance demonstrated in ATP-HEIF-0001 (there are no seismic requirements) 
31
Are coatings (or finishes) compatible with the expected environment? With expected usage?

Are surface finish requirements the least $x$ stringent possible?

Are required tolerances fabrication techniques, processes, etc. consistent with standard practices?

Can the design and its parts be easily inspected for conformance to engineering specifications?

Can the hardware be adequately disposed of after use if it is radiologically or chemically contaminated?

Have requirements for storing the equipment item been defined?

Have adequate acceptance criteria been specified and are the verification methods stated appropriately?

N/A

Have welding, bolting. joining methods $x$ been adequately specified?

N/A

Have NOE methods been applied correctly? $X$

Will a separate Acceptance Test Spec/Procedure be required?

- If yes, identify responsible organization(s) for preparation and issue (TBD if unknown)

Have human factors engineering and operability been considered?

Is an Operation and Maintenance Manual required? If so, have requirements been clearly identified?

Are current operating documents

(procedures. specifications, etc.) applicable to the design or are changes necessary?
OPEN, pending drawing approval for release
Equipment is designed for outdoor use, storage requirements to be defined by CED during procedure development

Ref. ATP-HEIF-0001

NDE not required ATP prepared by Merrick. approved by CED

Provided by vendor

To be provided by CFE 
52
Does the design use engineered safety and $x$ operational protections to avoid an excessive risk-taking dependence on administrative infallibility?

Are reliability requirements specified? If so, does the reliability analysis of the design meet the specified reliability requirements?

Have all credible non-standard conditions $x$ been properly considered?

Is the equipment, system, or facility operabie?

Is the equipment design adequate to implement the proposed maintenance philosophy?

If any development work is needed, has it $X$ been funded or performed?

Has drawing traceability been provided? $x$

Has the need for safety analysis of this $x$ design been determined by Safety?

Is the equipment, system. or facility covered by an existing Safety Analysis Report? If not. complete the safety analysis in time to incorporate findings of the analyzed in the design.

Does the design match the intended (and possible abnormal) methods of operation of the systen or facility?

$$
\text { N/A }
$$

Is a single point failure anaiysis required?

Are all indication lights and electrical $x$ control considered fail-safe?

Do the design media. format, content. reproducibility, and quality comply with all applicable requirements (including Hanford Plant Standards and referenced codes and standards)? Are the drawings structured to meet the needs of users after project completion?

Have availability of power requirements for the project been verified?

Have requirements for providing as-built $x$ drawings been specified?

Is the design in compliance with applicable regulatory requirements and/or $X$ WHC regul atory commi tments?

Are design tolerances appropriate and applied in a cost-effective manner and are standard materials and material sizes used where practicable?

Is all computer software and data properiy identified and controlled?
Ref. SA and Merrick report \#MLC-003

Ref. SA

Equipment will not be fully operational until OTP

Maintenance philosophy to be addressed during development of maintenance procedures

OPEN. pending drawing approval for release 
WHC-SD-WM-DRR-051, Rev. 0

Page A3-1

\section{ATTACHMENT 3}

Copies of RCR's 


\begin{tabular}{|l|l|l|}
\hline \multirow{2}{*}{ REVIEW COMMENT RECORD (RCR) } & $\begin{array}{l}\text { 1. Date } \\
\text { January 22, 1996 }\end{array}$ & $\begin{array}{l}\text { 2. Review No. } \\
29-96\end{array}$ \\
\cline { 2 - 4 } & 3. Project wo. & 4. Page \\
\hline
\end{tabular}

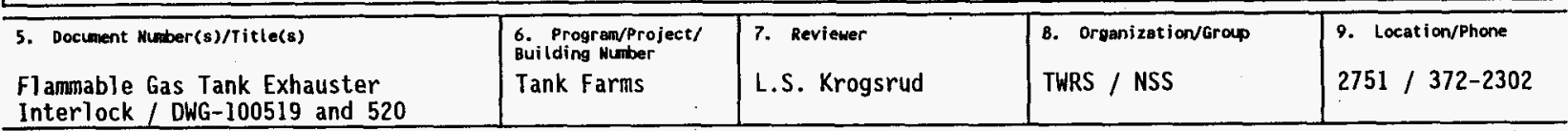

17. Comment Subaittal Approval: 10 . Agreement with indicated conment disposition(s)

Organization Manager (Optional)
24 Apil 96

11. CLOSED

\section{$\frac{24}{\text { oate }} 176$}

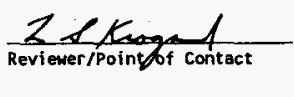

Author/originator

Author/originator

\begin{tabular}{|c|c|c|c|c|}
\hline \\
\hline $\begin{array}{l}12 . \\
1 \text { tem }\end{array}$ & $\begin{array}{l}\text { 13. Comment( }(s) / 0 \text { iscrepaney(s) (Provide technical justification for the } \\
\text { comment and detailed recommendation of the action required to correct/ } \\
\text { resolve the discrepancy/problen indicated.) }\end{array}$ & $\begin{array}{l}14 . \\
\text { Hold } \\
\text { Point }\end{array}$ & 15. Disposition (Provide justification if NOT accepted.) & $\begin{array}{l}16 . \\
\text { Status }\end{array}$ \\
\hline 1. & $\begin{array}{l}\text { On sheet } 2 \text { of } 3 \text { there is a problem with the wires } \\
\text { which run from } F 6 \text { to } A 6 \text {. The top of the right-most } \\
\text { wire says } 120 \mathrm{v} \text {, and at the bottom the same wire says } \\
24 \mathrm{v} \text {. Also when going from zone } A 7 \text { to } F 3 \text {, three } \\
\text { wires suddenly become four. Recommend following } \\
\text { these wires on all } 3 \text { sheets to make sure they start } \\
\text { and stop at the right places and that they are } \\
\text { labeled correctly. }\end{array}$ & & Accept & C \\
\hline 2 & $\begin{array}{l}\text { On page } 7 \text { (section } 4.2 .1 \text { ) Flammable Gas Tank } \\
\text { Exhauster Interlock Software Design Description, it } \\
\text { refers to contact TK1. I couldn't find TK1 on the } \\
\text { drawings. }\end{array}$ & & Accept & C \\
\hline
\end{tabular}




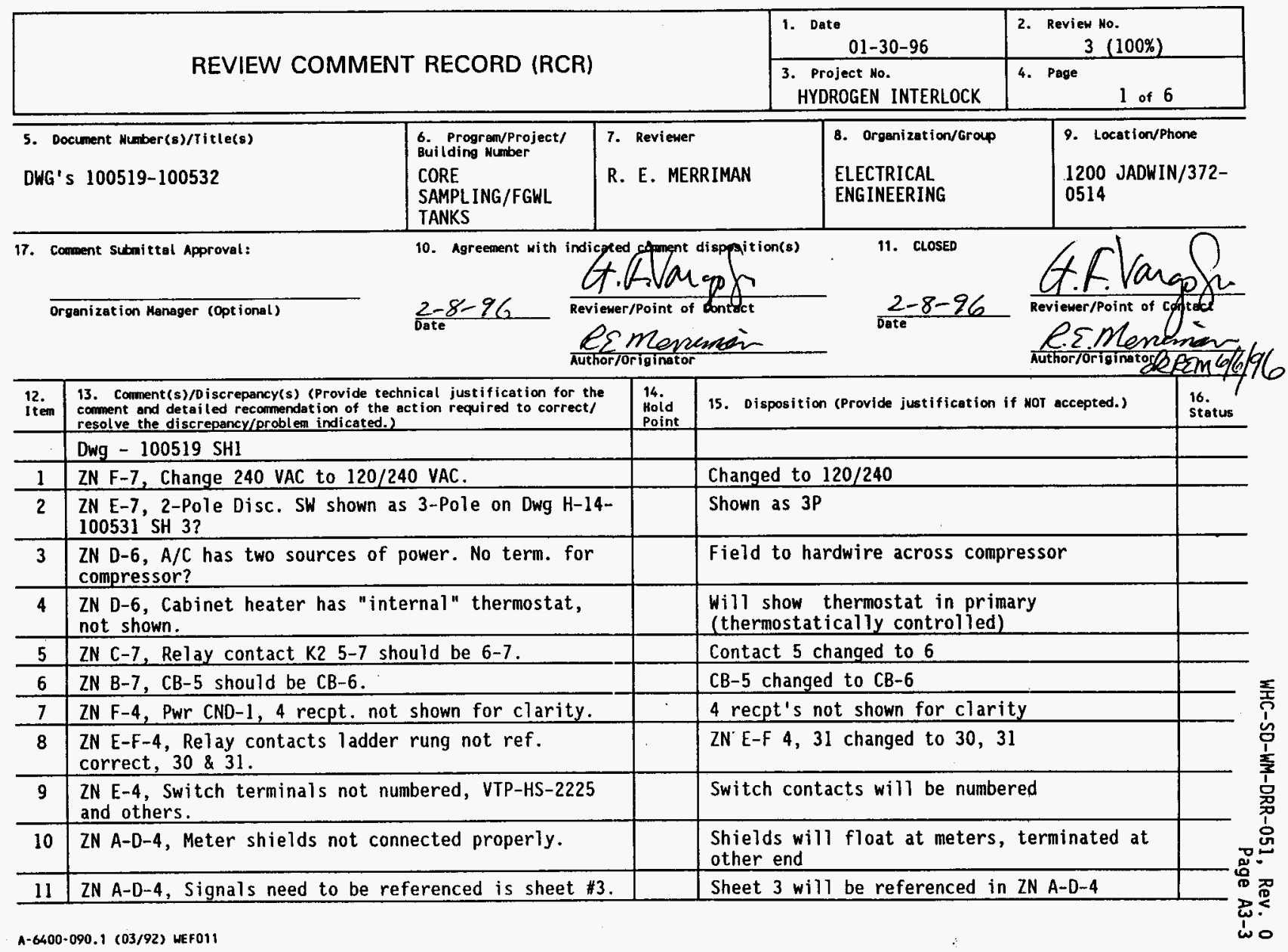




\begin{tabular}{|c|c|c|c|c|c|}
\hline \multirow{2}{*}{\multicolumn{3}{|c|}{ REVIEW COMMENT RECORD (RCR) }} & 1. Date $01-30-96$ & \multicolumn{2}{|c|}{$\begin{array}{l}\text { 2. Review No. } \\
3(100 \%)\end{array}$} \\
\hline & & & $\begin{array}{l}\text { 3. Project No. } \\
\text { HYDROGEN INTERLOCK }\end{array}$ & \multicolumn{2}{|l|}{ 4. Page } \\
\hline \begin{tabular}{l|l} 
12. \\
Item
\end{tabular} & $\begin{array}{l}\text { 13. Comment(s)/Discrepency(s) (Provide technical justification for the } \\
\text { comment and detailed recommendation of the action required to correct/ } \\
\text { resolve the discrepancy/problem indicated.) }\end{array}$ & $\begin{array}{l}14 . \\
\text { Hoid } \\
\text { Point } \\
\end{array}$ & \multicolumn{2}{|c|}{ 15. Disposition (Provide justification if MOT accepted.) } & $\begin{array}{l}16 . \\
\text { Status }\end{array}$ \\
\hline 12 & $\begin{array}{l}\text { ZN C-3, Signal wires reversed } 2101,2102 \& 2401 \text {, } \\
2402 \text {, Ref. } 100531 \text { SH } 1 \text {. }\end{array}$ & & \multicolumn{2}{|c|}{$\begin{array}{l}2101 \& Z 102 \text { also } 2401 \text { and } 2402 \text { will be } \\
\text { reversed. }\end{array}$} & \\
\hline \multirow[t]{2}{*}{13} & $\begin{array}{l}\text { ZN B-4, At FU6 1abel wire } 2801 \text { (Ref. 100531, SH 1) } \\
\text { not } 2601 \text {. }\end{array}$ & & \multicolumn{2}{|c|}{ FU6 should go to 2801 , not 2601} & \\
\hline & SHEET 2 & & & & \\
\hline 14 & ZN B-F-4, Remove wire "+24VDC". & & Wire +24 VDC removed & & \\
\hline 15 & $\begin{array}{l}\text { ZN F-8, Extend at FU7 wire } 3101 \text { to Sheet } 3 \text {. Device } \\
\text { PLC (Siot 9) Term } 1 \text { change at Dwg. } \mathrm{H}-14-100531 \text {. }\end{array}$ & & \multicolumn{2}{|l|}{ Wire 3101 extended to sheet 3} & \\
\hline \multirow[t]{2}{*}{16} & ZN C-3, change "spare" to "space" output \#20 \& \#21. & & \multicolumn{2}{|l|}{ Outputs $20 \& 21$ are spare } & \\
\hline & SHEET 3 & & \multirow{2}{*}{\multicolumn{2}{|c|}{ Term 11 clarified }} & \\
\hline 17 & ZN F-3 \& $D-3$, clear text at module Term 11. & & & & \\
\hline 18 & ZN B-3, Does VTP-PS-2205 need a power ground? & & \multicolumn{2}{|l|}{ Ground added } & $\cdot$ \\
\hline \multirow[t]{2}{*}{19} & $\begin{array}{l}\text { ZN A-3, Wires } 9801 \text { and } 9802 \text { Ref. J8A connector and } \\
\text { Dwg, to go to } \mathrm{H}-14-100531 \text {, Sh. } 3, \mathrm{ZN} \mathrm{E6.}\end{array}$ & & \multicolumn{2}{|c|}{ Connector J8A referenced $\mathrm{w} / \mathrm{dwg} \#$ and $\mathrm{sh} \#$} & \\
\hline & DWG-100520 SH 1-3 & & & & \\
\hline \multirow[t]{3}{*}{20} & Same comments as 1-19 above. & & \multicolumn{2}{|l|}{ Same resolution for dwg 100520} & \\
\hline & & & \multicolumn{2}{|l|}{ Sheets $1-3$ as for dwg 100519} & \\
\hline & DWG-100521 SH 1 & & \multirow{2}{*}{\multicolumn{2}{|c|}{$\begin{array}{l}\text { Item } 19 \& 20 \text { are } \mathrm{rad} 1 / 3 / 4 \text {, sheet } 12 \text { will } \\
\text { change }\end{array}$}} & \\
\hline 21 & $\begin{array}{l}\text { ZN E-2, Item No. } 19 \& 20 \text { Rad } 13 / 4 \text {, does not match } \\
\text { Det } 19 \& 20 \text { on Sheet } 12 \text {. }\end{array}$ & & & & \\
\hline 22 & Sht 2, ZN D-6, Item 161, should be "output" module. & & \multicolumn{2}{|l|}{ Changed to "output" } & \\
\hline 23 & $\begin{array}{l}\text { Sht } 4 \text {, Add note that Cart I is } 2205 \& \text { II is } 2206 \text {, } \\
\text { all Dwgs where Cart I and II are shown. }\end{array}$ & & \multicolumn{2}{|l|}{ Note will be added } & \\
\hline
\end{tabular}




\begin{tabular}{|c|c|c|c|c|c|}
\hline \multirow{2}{*}{\multicolumn{3}{|c|}{ REVIEW COMMENT RECORD (RCR) }} & \multirow{2}{*}{$\begin{array}{l}\text { 1. Date } \\
01-30-96 \\
\text { 3. Project Ho. } \\
\text { HYOROGEN INTERLOCK }\end{array}$} & \multicolumn{2}{|l|}{$\begin{array}{l}\text { 2. Revien No. } \\
\qquad 3(100 \%)\end{array}$} \\
\hline & & & & \multicolumn{2}{|c|}{3 of 6} \\
\hline itew & $\begin{array}{l}\text { 13. Comment(s)/Discrepency(s) (Provide technical justification for the } \\
\text { comment and detailed recomnendation of the action required to correct/ } \\
\text { resolve the discrepency/problem indicated.) }\end{array}$ & $\begin{array}{l}\text { 14. } \\
\text { Hoold } \\
\text { Point }\end{array}$ & \multicolumn{2}{|c|}{ 15. Disposition (Provide justification if NOT accepted.) } & $\begin{array}{l}16 . \\
\text { Status }\end{array}$ \\
\hline 24 & $\begin{array}{l}\text { Sht } 5 \text {, ZN B-4, Item } 12 \text {, show as "Ref" for second } \\
\text { call out, all dwgs. }\end{array}$ & & \multicolumn{2}{|c|}{ Added ref to item 12 on all dwgs } & \\
\hline 25 & Sht 11 , ZN F-7, Item 35 should it be $36 ?$ & & \multicolumn{2}{|l|}{ ZN F-7 change to item 36} & \\
\hline 26 & Sht 12 , Det $19 \& 20$ See comment \#21. & & \multicolumn{2}{|c|}{$\begin{array}{l}\text { Matl is } 13 / 4 \text { item } 19 \text { dia is } 1.33 \text {, item } 20 \\
\text { dia is as follows }-1.25,1.33 \text { and } 1.50\end{array}$} & \\
\hline 27 & Sht 12, Det 17 , Dim 3.92 has extra arrow on top. & & \multicolumn{2}{|l|}{ Remove arrow } & \\
\hline 28 & Sht 15, Add I0 for T.B. $1,2 \& 3$, like $K$ 's \& CB's. & & \multicolumn{2}{|l|}{ Yes, added idents } & \\
\hline 29 & $\begin{array}{l}\text { Sht } 15, \text { ZN D-6, to the right of Item } 159 \text { add } \\
\text { "SPARE." }\end{array}$ & & \multicolumn{2}{|l|}{ No, not on hardware dwg } & \\
\hline 30 & Sht 16, ZN F-7, name plate $C$ add "DS4", D add "DS1." & & \multicolumn{2}{|l|}{ Add DS4, not on DS1 its spare } & \\
\hline 31 & $\begin{array}{l}\text { Sht } 16, \text { ZN B-8, where are AG-AL \& AS name plates } \\
\text { shown. }\end{array}$ & & \multicolumn{2}{|c|}{$\begin{array}{l}\text { AG on sh } 1 \text { on item } 50 \text {, AH on Sht } 3 \text { on item } \\
88 \text { AJ on sht } 2 \text { on item } 89 \text { AK near item } 90 \text {, } \\
\text { AL near item } 125 \text { on sht. } 3 \text {, AS near item } 59 \\
\text { on sht. } 15\end{array}$} & \\
\hline \multirow[t]{2}{*}{32} & $\begin{array}{l}\text { Sht 16, Add titles to three units on right side of } \\
\text { Dwg. }\end{array}$ & & \multicolumn{2}{|l|}{ Correct, titles will be added } & $\cdot$ \\
\hline & DWG $\mathrm{H}-14-100522$ & & & & \\
\hline 33 & Sht 1, ZN E-7, change Exhauster "motor" to "Power". & & \multicolumn{2}{|l|}{ Correct, power } & \\
\hline \multirow[t]{2}{*}{34} & Sht $1, Z N$ D-E-5, Ref. Cart I is $2205 \&$ II is 2206. & & \multicolumn{2}{|c|}{ Cart 1 is 2205 and cart 2 is 2206 change ID } & 玨 \\
\hline & DWG $\mathrm{H}-14-100523$ & & \multicolumn{2}{|l|}{. } & $F$ \\
\hline 35 & $\begin{array}{l}\text { Sht } 1 \text {, Item } 19 \text {; show STAHL is UL labeled, not clear } \\
\text { from manufacturer data. Was it labeled when } \\
\text { received? }\end{array}$ & & \multicolumn{2}{|l|}{ Item 19 is UL approved } & \\
\hline 36 & $\begin{array}{l}\text { Sht 2, ZN B-7, Plugs P7B \& P13B wiring does not } \\
\text { match jumper cable or source, see } 100531 \text { Sht } 3 \text {. }\end{array}$ & & \multicolumn{2}{|c|}{$\begin{array}{l}\text { Wiring will be changed to match } 100531 \text { sht. } \\
3 \text { output from J7A and J13A }\end{array}$} & \\
\hline
\end{tabular}




\begin{tabular}{|c|l|l|}
\hline \multirow{2}{*}{ REVIEW COMMENT RECORD (RCR) } & $\begin{array}{l}\text { 1. Date Review Ho. } \\
01-30-96\end{array}$ & $\begin{array}{l}3 . \\
\text { (100\%) }\end{array}$ \\
\cline { 2 - 3 } & $\begin{array}{l}3 . \text { Project Ho. } \\
\text { HYDROGEN INTERLOCK }\end{array}$ & $\begin{array}{l}4 . \text { Page } \\
4\end{array}$ \\
\hline
\end{tabular}

\begin{tabular}{|c|c|c|c|c|}
\hline $\begin{array}{l}\text { 12. } \\
\text { Item }\end{array}$ & $\begin{array}{l}\text { 13. Comment(s)/Discrepancy(s) (Provide technical justification for the } \\
\text { comment and detailed recomendation of the action required to correct/ } \\
\text { resolve the discrepancy(problem indicated.) }\end{array}$ & $\begin{array}{l}14 . \\
\text { Hoid } \\
\text { Point } \\
\end{array}$ & 15. Disposition (Provide justification if NOT accepted.) & $\begin{array}{l}\text { 16. } \\
\text { status } \\
\end{array}$ \\
\hline 37 & $\begin{array}{l}\text { Sht } 2 \text {, ZN B-7, why are system grounds tied together? } \\
\text { See Dwg. } 100531 \text {, SH } 1 \text { Note } 4 \text {, requires independent } \\
\text { ground systems. }\end{array}$ & & $\begin{array}{l}\text { Shields will be independent dwg will be } \\
\text { changed. }\end{array}$ & \\
\hline 38 & $\begin{array}{l}\text { Sht } 2 \text {, ZN B-7, wiring of barriers does not match } \\
\text { manufacturing wiring shown with review package. }\end{array}$ & & Agreed, dwg will be changed & \\
\hline \multirow[t]{2}{*}{39} & Sht $2, Z N$ B-6, what is device "circle $w /+-" 1$ abel. & & Whittaker devices will be identified & \\
\hline & DWG-H-14-100524 Sht 1 & & & \\
\hline \multirow[t]{2}{*}{40} & ZN F-1, item 5 , change "indicator" to "sensor". & & Agree & \\
\hline & DWG-H-14-100530 Sht 1 & & Agree & \\
\hline 41 & $\begin{array}{l}\text { ZN E-7, change VTP-MS-2205 Motor "starter" to } \\
\text { "contactor" 2-PL. }\end{array}$ & & Agree & \\
\hline 42 & Identify Cart I and II as $2205 \& 2206$. & & Agree & \\
\hline 43 & At interconnection plugs, provide ref. dwg. & & They are rated NEMA 3R & \\
\hline 44 & $\begin{array}{l}\text { Item } 12 \text {, contactor enclosure should be outdoor } \\
\text { rated. }\end{array}$ & & - Agreed, will recheck and change & \\
\hline \multirow[t]{2}{*}{45} & Power distribution schedule, amp loads are too high. & & 8 & \\
\hline & DWG H-14-100531 Sht 1 & & & \\
\hline 46 & $\begin{array}{l}\text { ZN F-8, VTP-AC-2205 compressor terminations? Not } \\
\text { separate from } L 1 \& \text { L } 2 \text {. }\end{array}$ & & Yes we are hardwiring blower from compressor & \\
\hline 47 & ZN A-8, VTP-HTR-2205, internal thermostat. & & Agree will show it & \\
\hline 48 & Move 5 panel meters to Sht 2 from PNL. & & Will separate the two views & \\
\hline 49 & $\begin{array}{l}\text { Meter VTP-MON-2207, is FU6-PI-1 wire "2801" is it } \\
\text { correct? }\end{array}$ & & Correct it is wire 2801 & \\
\hline 50 & TB1, CB-1 should be $30 \mathrm{~A}$ not $20 \mathrm{~A}$. & & Agree 30A & \\
\hline
\end{tabular}




\begin{tabular}{|l|l|l|}
\hline \multirow{2}{*}{ REVIEW COMMENT RECORD (RCR) } & $\begin{array}{l}\text { 1. Date } \\
01-30-96\end{array}$ & $\begin{array}{l}\text { 2. Review Mo. } \\
\text { (100\%) }\end{array}$ \\
\cline { 2 - 4 } & $\begin{array}{l}\text { 3. Project No. } \\
\text { HYDROGEN INTERLOCK }\end{array}$ & $\begin{array}{l}4 . \quad \text { Page } \\
5\end{array}$ \\
\hline
\end{tabular}

\begin{tabular}{|c|c|c|c|c|}
\hline $\begin{array}{l}12 . \\
\text { Item }\end{array}$ & $\begin{array}{l}\text { 13. Comment(s)/o iscrepancy(s) (Provide technical justification for the } \\
\text { comment ond detai led recomendat ion of the action required to correct/ } \\
\text { resolve the discrepancy/problem indicated.) }\end{array}$ & $\begin{array}{l}\text { P4. } \\
\text { Hoid } \\
\text { Point }\end{array}$ & 15. Disposition (Provide justification if NOT accepted.) & $\begin{array}{l}16 . \\
\text { Status }\end{array}$ \\
\hline 51 & $\begin{array}{l}\text { TBl, All VTP should have terminal numbers added to } \\
\text { device number several locations. }\end{array}$ & & Agree & \\
\hline 52 & TB2, Term 7-8 remove one of the jumpers. & & Agree & \\
\hline 53 & Relay $\mathrm{Kl}$, Term 11 can't read PwrCND. & & Correct will clean up & \\
\hline 54 & Label "Rear" Panel "back" ref 100521 Sht 15. & & Agree & \\
\hline 55 & VTP-PS-2205, J8A-E\&F Ref. Sht \#3, ZN D6. & & Agree & \\
\hline 56 & VTP-HM-2205, Remove line between $\mathrm{K5}-10$ and Term 9 . & & Agree & \\
\hline 57 & Note 5. How small can wire be? & & Will add .. shall be 16-18 AWG type MTW & \\
\hline 58 & $\begin{array}{l}\text { At meters, shield grounds are not shown connected } \\
\text { correctly, consistently. }\end{array}$ & & Agree will terminate shield ends & \\
\hline 59 & $\begin{array}{l}\text { Sht 2, Add note to top on panel "See Sht } 1 \text { for } \\
\text { Meters." }\end{array}$ & & Agree & \\
\hline 60 & Sht 2, Slot 1, Identify connector at bottom Jl. & & Agree & \\
\hline 61 & $\begin{array}{l}\text { Sht 2, slot 10, change label from "spare" to } \\
\text { "space." }\end{array}$ & & $\begin{array}{l}\text { No, they are spare, not terminated they are } \\
\text { not empty }\end{array}$ & - \\
\hline 62 & Sht 2 , Relay K12, term 1 ref $\mathrm{K} 9-1$ ? & & See dwg 100519 sht 2 (jumper) & \\
\hline 63 & Sht 2 , ZN D-4 remove "wire no. 9501 " by FU10. & & Agree, should be 8501 & \\
\hline 64 & Sht 2, TB3. Is ground correct here? & & Will delete & \\
\hline \multirow[t]{2}{*}{65} & $\begin{array}{l}\text { Sht } 2 \text {, Resistor "tolerance", "call out," and should } \\
\text { it be connected in series? }\end{array}$ & & Yes in series, will add tolerance & \\
\hline & SHT 3 & & & \\
\hline 66 & ZN E-8, VTP-0S-2207 shown upside down. & & Correct, will reverse & \\
\hline 67 & $\begin{array}{l}\mathrm{ZN} \mathrm{C}-7 \text {, at } \mathrm{Pl} \& \mathrm{Jl} \text { redundant to power cable at } \\
\text { generator. Is cable type called out? }\end{array}$ & & $\begin{array}{l}\text { Will change ident, cable type identified on } \\
\text { H14-100522, sht 2. }\end{array}$ & \\
\hline 68 & ZN E-6, At J6A confirm exhauster connections. & & Agree, will confirm and document & \\
\hline
\end{tabular}




\begin{tabular}{|c|c|c|}
\hline & $\begin{array}{l}\text { 1. Date } \\
01-30-96 \\
\end{array}$ & $\begin{array}{r}\text { 2. Review No. } \\
3(100 \%) \\
\end{array}$ \\
\hline REVIEW COMMENT RECORD (RCR) & $\begin{array}{l}\text { 3. Project No. } \\
\text { HYDROGEN INTERLOCK }\end{array}$ & 4. Page 6 of 6 \\
\hline
\end{tabular}

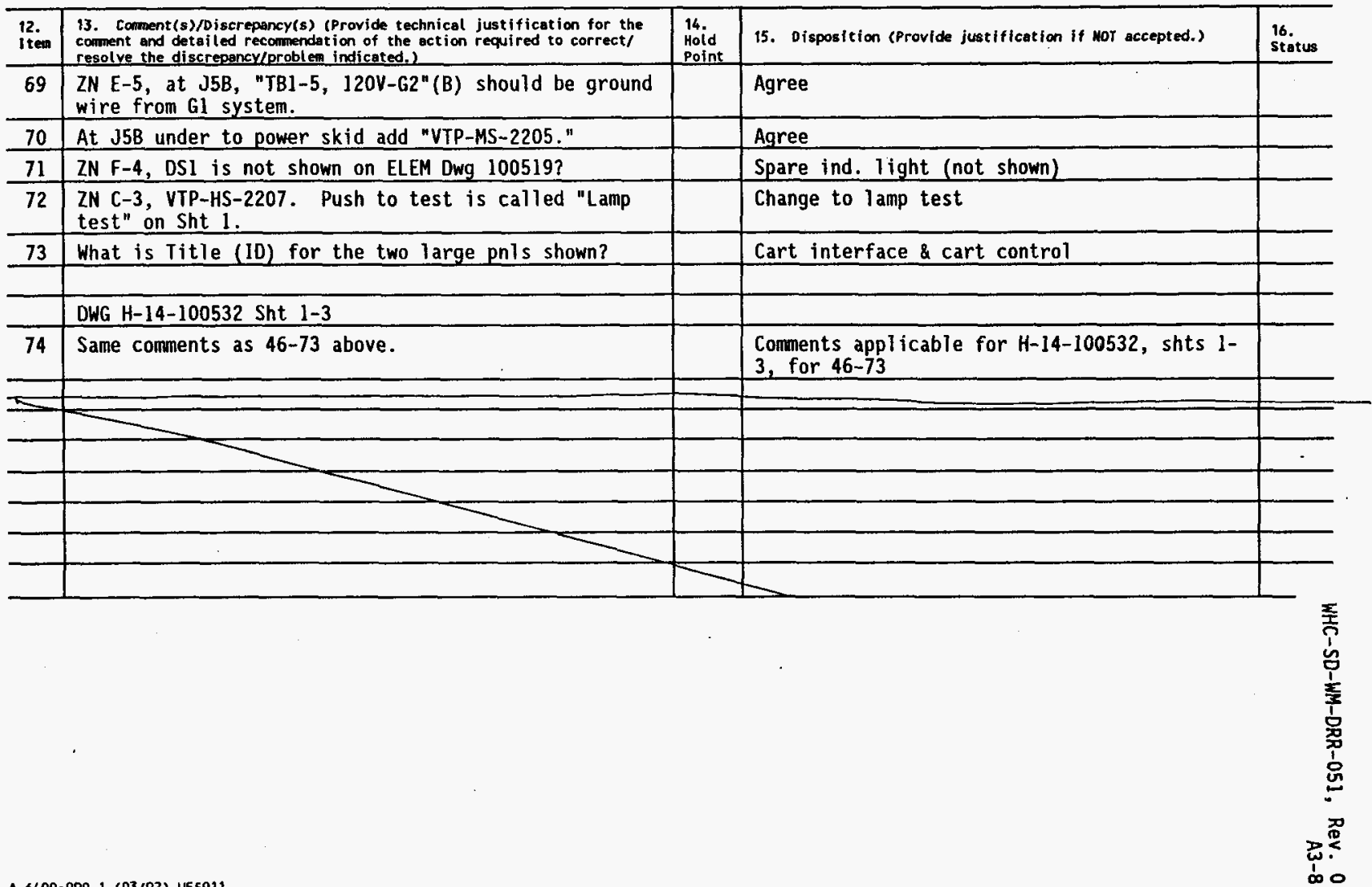




\begin{tabular}{|c|c|c|}
\hline & $\begin{array}{l}\text { 1. Date } \\
3 / 12 / 96\end{array}$ & $\begin{array}{l}\text { 2. Revien No. } \\
100 \%\end{array}$ \\
\hline REVIEV CUMIVIEIN I RELURD (RLK) & $\begin{array}{l}\text { 3. Project No. } \\
\text { ETN-96-003 }\end{array}$ & 4. Page \\
\hline
\end{tabular}

\section{Document Number(s)/Title(s)}

See block 13

17. Combent Sumittal Approval:

Organization Mansger (Optional)

\begin{tabular}{l|l}
$\begin{array}{l}\text { 6. Program/Project/ } \\
\text { Building Mumber } \\
\text { Characterization }\end{array}$ & 7. Reviewer \\
RMCS & J. Marte11
\end{tabular}

10. Agreement with indicated comment disposition(s)

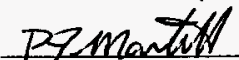

$3-12-96$

Reviener/pointequan... Date
8. Organization/Group

WCS/ES
9. Location/Phone

M0255/373-5417

\section{Author/origineter}

11. CLOSED

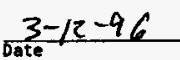

ReV

Prolam $/ 1 / 1$

Reviewer/Point-of-Gontect

Muthor/ortsinator

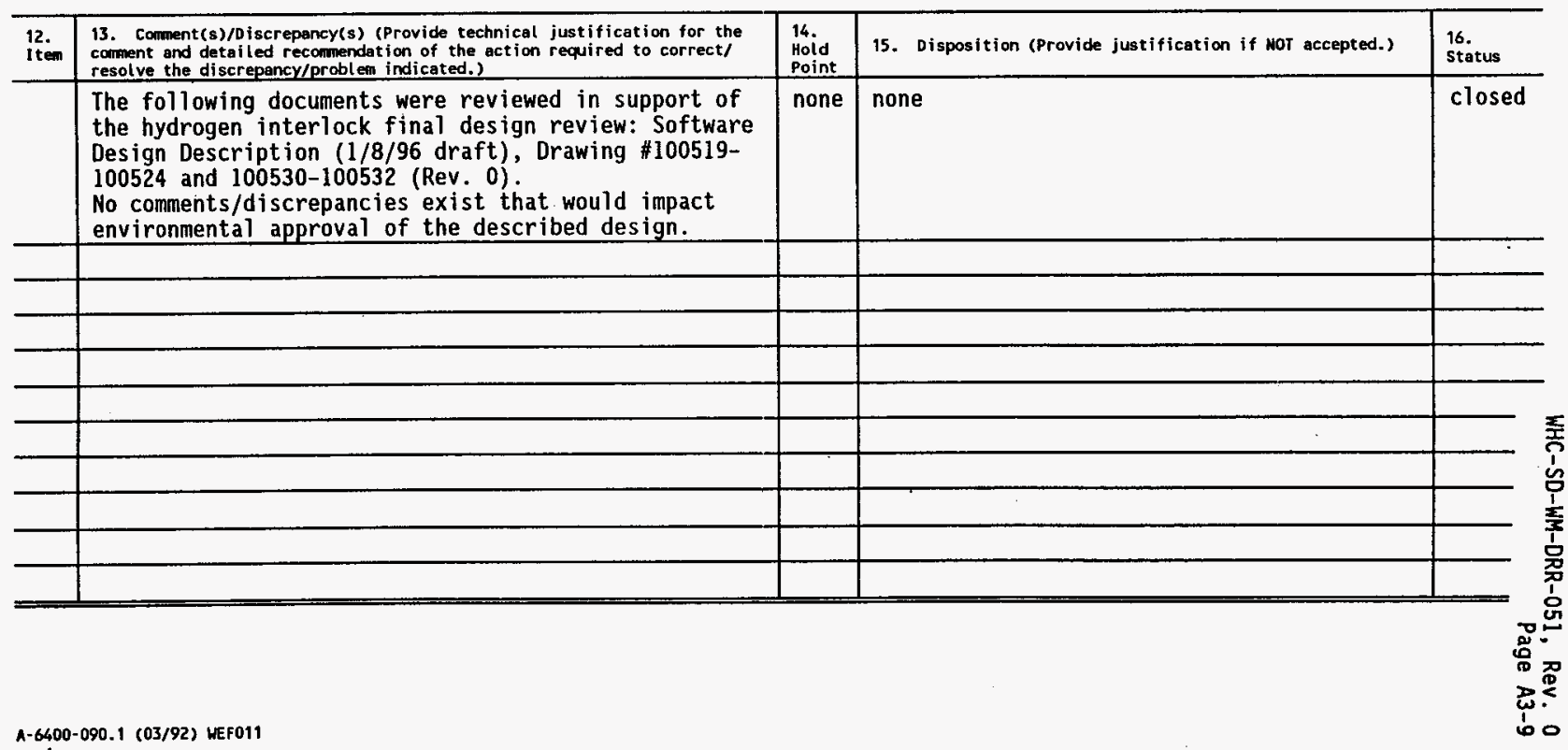




\begin{tabular}{|l|l|l|l|}
\hline REVIEW COMMENT RECORD (RCR) & $\begin{array}{l}\text { 1. Date } \\
3 / 12 / 96\end{array}$ & $\begin{array}{l}2 . \text { Review No. } \\
100 \%\end{array}$ \\
\cline { 2 - 3 } & $\begin{array}{c}3 . \text { Project Ho. } \\
\text { ETN-96-003 }\end{array}$ & $\begin{array}{l}4 . \text { Page } \\
1 \text { of } 1\end{array}$ \\
\hline
\end{tabular}

5. Document Number(s)/Title(s)

See block 13

17. Coment Submittal Approval:

Organization Manager (Optionat)

\begin{tabular}{l|l}
$\begin{array}{l}\text { 6. Program/Project/ } \\
\text { Building Number }\end{array}$ & 7. Reviewer \\
Characterization & L. S. Krogsrud \\
RMCS
\end{tabular}

10. Agreement with indicated comment disposition(s)

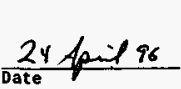

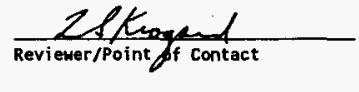

Author/0riginator
8. Organization/Group

TWRS Safety
9. Location/Phone

2751E/372-2302

\section{CLLSED}

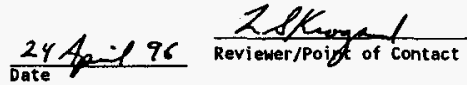
Date 76

Author/Originator

\begin{tabular}{|c|c|c|c|c|}
\hline $\begin{array}{l}12 . \\
\text { iterp }\end{array}$ & $\begin{array}{l}\text { 13. Comment }(s) / D \text { iscrepancy(s) (Provide technical justification for the } \\
\text { comment and detailed recommendation of the action required to correct/ } \\
\text { resolve the discrepancy/problem indicated.) }\end{array}$ & $\begin{array}{l}14 . \\
\text { Hoid } \\
\text { Point }\end{array}$ & 15. Disposition (Provide Justification if Nor accepted.) & $\begin{array}{l}16 . \\
\text { Status }\end{array}$ \\
\hline & $\begin{array}{l}\text { The following documents were reviewed in support of } \\
\text { the hydrogen interlock final design review: Software } \\
\text { Design Description ( } 1 / 8 / 96 \text { draft), Drawing } \# 100521 \text { - } \\
100524 \text { and } 100530-100532 \text { (Rev. 0). } \\
\text { No comments/discrepancies exist that would impact } \\
\text { TWRS Safety of the described design. }\end{array}$ & none. & none & closed \\
\hline & & & & \\
\hline & & & & \\
\hline & & & & \\
\hline & & & & \\
\hline & & & & \\
\hline & & & & \\
\hline & & & & \\
\hline
\end{tabular}




\section{ATTACHMENT 4}

Meeting Minutes 
Subject: FORMAL DESIGN REVIEW MEETING - HYDROGEN INTERLOCK, KICKOFF

$\begin{array}{llllc}\begin{array}{l}\text { Department-Operation- } \\ \text { Component }\end{array} & \text { Area } & \text { Shift } & \text { Date of Meeting } & \begin{array}{c}\text { Number } \\ \text { Attending }\end{array} \\ \text { CHARACTERIZATION EQUIPMENT } & 200 E & 1 & \text { JANUARY 10,1996 } & 11\end{array}$

ATTENDEESS:

RAY MERRIMAN M.E.HUDA G.F. VARGO JR. ROY BLANCHARD JIM ROBINSON F.A. SCHMORDE ROSS TRUITT SAM SMITH WAYNE SHEPARD BOB WHITE BILL MANGRAN

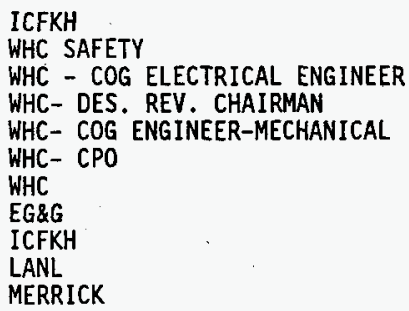

The meeting was called to order by the chairman and the attendance sheet passed around. The purpose of the meeting was explained i.e., Kick-off meeting for the 100\% design review of the "RMCST exhauster Interlock, for flammable gas tanks". Jim Robinson and George Vargo reviewed the design package content and answered questions from the attendees.

Review Comment Record (RCR) sheets were requested to be completed by January 17, 1996 (to Jim Robinson) with the design review meeting to be scheduled for January 24, 1996.

Actions agreed to in the meeting:

1. Provide copies of the SOW to Merrick Jim Robinson to board members requesting copies.

2. Revise ETP to include "Prototype * Jim Robinson development" have quality and safety review. In addition define $A B U$ requirements. 
WHC-SD-WM-DRR-051, Rev. 0
Page A4-3

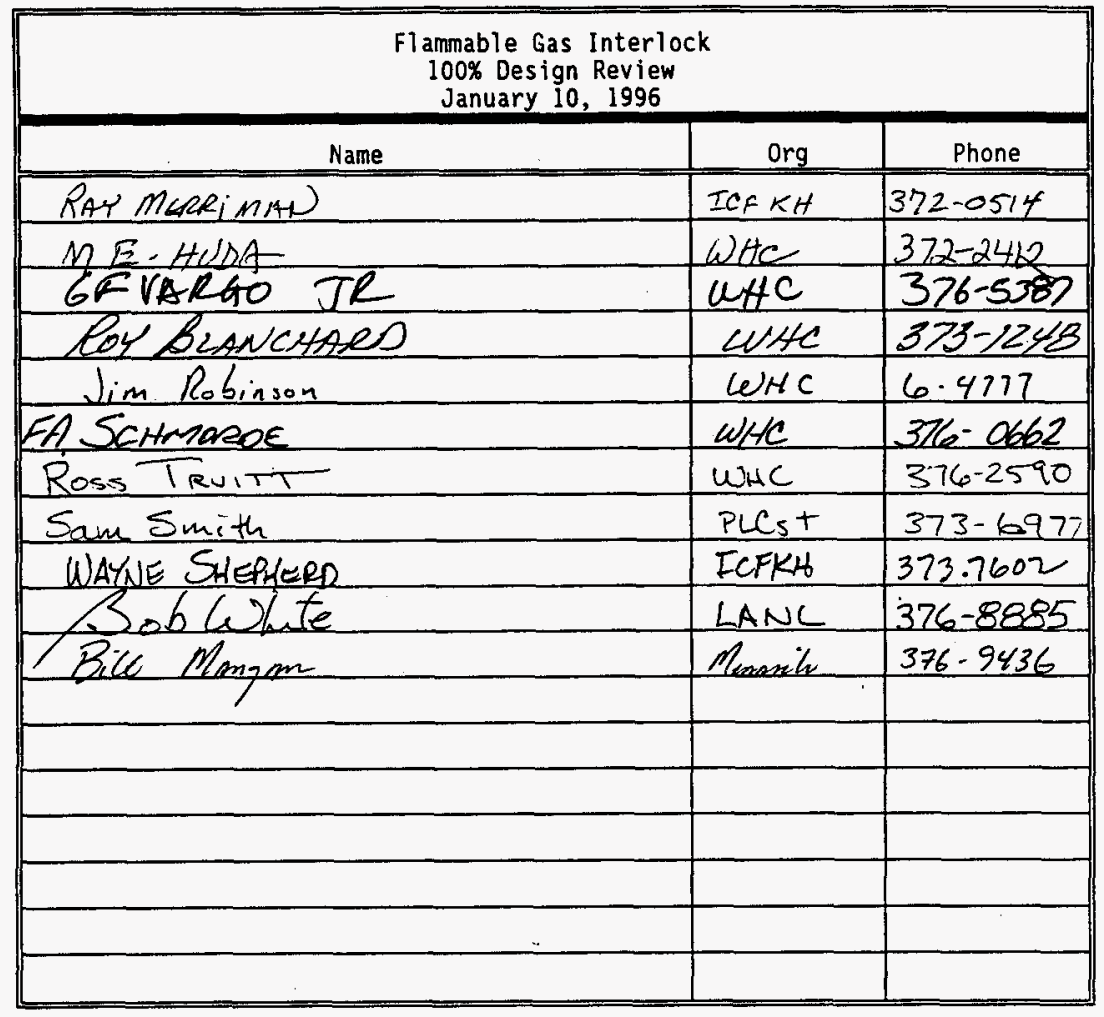


From: CHARACTERIZATION EQUIPHENT DESIGN

$75230-95-002$

Phone: $\quad 376-4777$ S7-12

Date: January 15,1996 :

Subject: DEVELOPMENT CONTROL REQUIREMENTS FOR FLAMMABLE GAS INTERLOCK

$\begin{array}{ll}\text { To: W. J. Mangan } & \text { H5-09 } \\ \text { cc: D. H. Hamilton } & 57-12 \\ \text { R. J. Blanchard } & 57-12 \\ \text { M. L. McElroy } & 57-07 \\ \text { M. E. Huda } & 57-07 \\ \text { G. F. Vargo } & \text { H5-09 } \\ \text { JDR: File LB } & \end{array}$

Reference: Hydrogen Interlock 100\% Design Review Meeting Hinutes.

This memo will formally document the flammable gas interlock drawing configuration control methodology. The interlock is being fabricated at H\&/N Electric in Pasco, Washington.

Merrick Engineering is responsible for fabrication. Use of this methodology will insure interlock design traceability.

In addition to this memo, the engineering task plan, WHC-SDWM-ETP-165, will be changed to include the configuration management requirements outl ined here. At minimum, Characterization ESQ representatives will review the Engineering Change Notice.

The cognizant engineer for the flammable gas interlock is James Robinson. The cognizant electrical engineer is George Vargo.

The configuration control methods described here follow the requirements of EP-2.4, Development Control Requirements as contained in WHC-CH-6-1, Standard Engineering Practices.

The flammable gas interlock has facility use potential. For this application the validation process as used in Paragraph 2.1.4 (a) of EP-2.4 is defined as the Operational Test. Asbuilt documentation (drawings) shall be released and incorporate all fabrication changes before turn over of the interlock to Characterization Project Operations (CPO).

H\&N Electric will maintain one set of drawings designated as the master set. Each sheet shali be lettered in red ink with the words, "Development Control," then signed and dated by the Merrick representative. 
All changes to the drawings shall be made in red ink, then signed and dated by the Merrick representative.

The Merrick representative may make minor modifications to the drawings without immediate verification by WHC cognizant engineers. Minor changes are defined as those that do not change the function of a selected component, alter the logic or sequence of operations of the programmabie logic controller (PLC), or change the material specification.

An example of a minor change would be a change in bolt length from $7 / 8$ inch to $3 / 4$ inch, if the bolt grade and material specification remained the same. As an example of a change that could not be made without WHC approval; Merrick could not alter the output value or range of any device used to gather, control, or transmit data.

The Merrick representative will maintain a log of all changes. At minimum, HHC cognizant engineers will review the log once a week. Each WHC cognizant engineer will maintain a complete set of drawings with each change marked in red.

If a drawing becomes illegible due to changes, that drawing shall be replaced with an updated drawing that reflects the changes to that date. The old drawing shall be maintained to provide traceability.<smiles>CCCC</smiles>

James D. Robinson, Advanced Engineer Characterization Equipment Design 


\section{MEETING MINUTES}

sUsJECT: Final Design Review Briefing $\# 2$, Hydrogen Interlock, RMCS Exhauster

\begin{tabular}{|c|c|c|c|c|}
\hline $\begin{array}{l}\text { TO: } \\
\text { Distribution }\end{array}$ & & \multicolumn{3}{|c|}{$\begin{array}{l}\text { BUILDING } \\
N / A\end{array}$} \\
\hline $\begin{array}{l}\text { FROM: } \\
\text { J. E. Corbett }\end{array}$ & & \multicolumn{3}{|c|}{$\begin{array}{l}\text { CHAIRMAN } \\
\text { R. J. Bl anchard }\end{array}$} \\
\hline $\begin{array}{l}\text { DEPARTMENT-OPERATION-COMPONENT } \\
\text { Characterization }\end{array}$ & $\begin{array}{l}\text { AREA } \\
200 E\end{array}$ & $\begin{array}{l}\text { SHzFT } \\
\text { Day }\end{array}$ & $\begin{array}{l}\text { DATE OF MEETING } \\
2 / 28 / 96\end{array}$ & $\begin{array}{l}\text { NUMBER ATtEnding } \\
\text { See Roster }\end{array}$ \\
\hline
\end{tabular}

The meeting was chaired by Roy $B \mathrm{~B}$ anchard. The list of attendees is recorded on the attached meeting roster.

Jim Robinson presented the meeting topic, which was a description of the redesigned spool piece. The design of the spool piece presented at the $100 \%$ design review kickoff incorporated two Whittaker cells for hydrogen gas concentration measurement. During development of the draft SA, LANL expressed a concern that combustible gas sensors should be used in the interlock instead of Whittaker cells, since the Whittaker cells only measure hydrogen. Jim presented design drawings showing the new spool piece, which can accommodate two combustible gas sensors, two whittaker cells, or one of each. Copies of the drawing will be sent out to committee members not present at the meeting.

A change to the design review committee assignments was announced: Ron Bafus will be reviewing the design for Characterization Field Engineering.

Review comments are requested, in RCR format, to John Corbett by March 6th. Committee members who do not have any comments are requested to submit a "no comment" RCR. There were no action items assigned at this meeting. 
HYDROGEN INTERLOCK FORMAL DESIGN REVIEN, Rotary Mode Core Sampling System

\section{MEETING ROSTER}

SUQJECT: FINAL DESIGN REVIEW BRIEFING \#2

DATE: $02 / 28 / 96$

LOCATION: $2704 \mathrm{HV} / \mathrm{G} 110$

CHARMAN: RJ Bl anchard

PROGRAM: Characterization

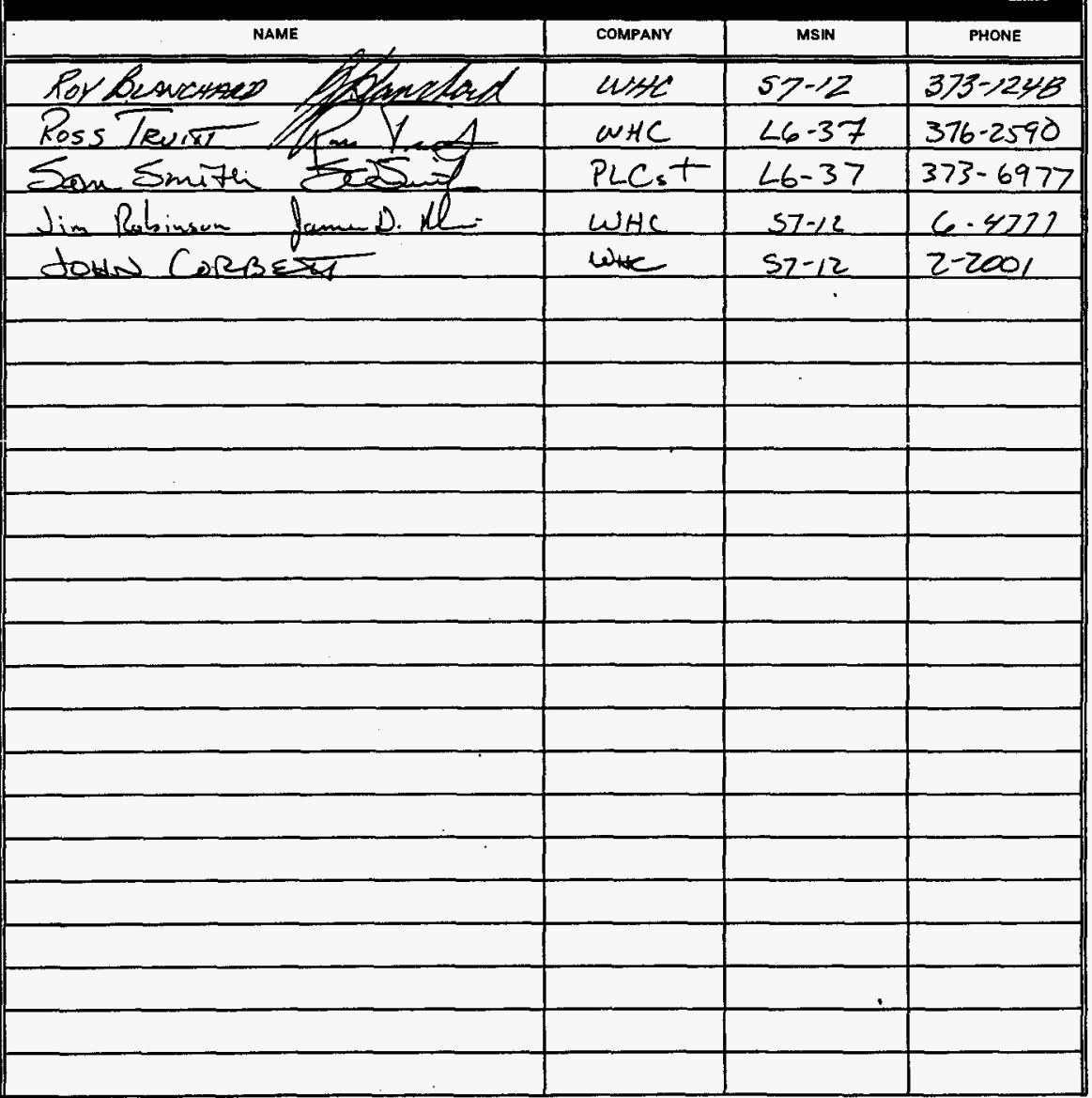


MEETING MINUTES

SUBdect: Final Design Review Closeout, Hydrogen Interlock, RMCS

\begin{tabular}{|c|c|c|c|c|}
\hline $\begin{array}{l}\text { TO: } \\
\text { Distribution }\end{array}$ & & \multicolumn{3}{|c|}{$\begin{array}{l}\text { BUILDING } \\
\text { N/A }\end{array}$} \\
\hline J. E. Corbett & & \multicolumn{3}{|c|}{$\begin{array}{l}\text { CHAIRMAN } \\
\text { R. J. Bl anchard }\end{array}$} \\
\hline $\begin{array}{l}\text { DEPARTMENT-OPERATION-COMPONENT } \\
\text { Characterization }\end{array}$ & $\begin{array}{l}\text { AREA } \\
200 E\end{array}$ & $\begin{array}{l}\text { SHIFT } \\
\text { Day }\end{array}$ & $\begin{array}{l}\text { DATE OF MEETING } \\
6 / 6 / 96\end{array}$ & $\begin{array}{l}\text { HUBER ATTEMDING } \\
\text { See Roster }\end{array}$ \\
\hline
\end{tabular}

The meeting was chaired by Roy Blanchard. The list of attendees is recorded on the meeting roster. The meeting consisted of the following agenda:

DESIGN STATUS Jim Robinson reported that design and fabrication is complete for all components of the Hydrogen Interlock. Debugging of the first cart is complete, and is progressing satisfactorily for the second cart.

RCR's

There were no new Review Comment Records since the previous meeting. The only open RCR was closed by Ray Merriman.

DRAWING STATUS The drawings were completed under development control. Robinson reported that redlines are currently being incorporated. The rediines are due to changes picked up during fabrication and debugging, as well as those due to previous design review comments. Drawing redlines do not represent significant changes to the design, as described in the design review briefings. The drawings will go through WHC checking.

Roy Blanchard proposed that the design review chairman signature for drawing release would act as the approval signature for each design review committee member. This proposal was accepted. After the drawings have gone through check, they will be sent to all committee members. Blanchard will sign after committee members have reviewed and approved the drawings.

SA STATUS

$\mathrm{Bl}$ anchard reported that the Safety Assessment for RMCS in flammable gas tanks was approved. There were no changes that impacted the hydrogen interlock design.

CHECKLIST

The design review checklist was reviewed. Dispositions and remarks were made by committee members. Items \#33 \& \#65 will be considered closed, in the affirmative, when the design drawings are approved for release. The completed checklist is attached.

CLOSING REMARKS The design review is complete, with the exception of drawing approval for release. Due to reorganizations/personnel changes, the following review committee assignments were made for the purpose of drawing release approval and design review report approval: Krogsrud is replaced by Omar Jaka, Bornemann/Martell replaced by Kathy Tollefson, and Straalsund replaced by the designated representative from Characterization Monitoring Development. Distribution of drawings for release approval is expected within two to three weeks. No further meetings are anticipated. 


\section{MEETING ROSTER}

SUBJECT:

HYDROGEN INTERLOCK FINAL DESIGN REVIEW CLOSEOUT Rotary Mode Core Sampling System Portable Exhauster

DATE: $6 / 6 / 96$

CHAIRMAN: RJ Blanchard

LOCATION: 2704HV/G133

PROGRAM: Characterization

\begin{tabular}{|c|c|c|c|}
\hline NAME & COMPANY & MSIN & PHONE \\
\hline Micmael L. $M \leq E_{\text {Leay }}$ & WHE & $57-07$ & $3-5588$ \\
\hline James 0. R.binson & whe & $57-12$ & $6-4777$ \\
\hline RAS E. MEReimal & ICF KH & $E 6-27$ & 2.0514 \\
\hline Eesperick 4 Semorea & WHC & $57-\phi 5$ & 6.4662 \\
\hline Hey I. DLswenseD & WHe & $57-12$ & $3-1248$ \\
\hline dona CorbezI & $\omega A C$ & $57-12$ & $2-2001$ \\
\hline & & & \\
\hline & & & \\
\hline & & & \\
\hline & & & \\
\hline & & & \\
\hline & & & \\
\hline & & & \\
\hline & & & \\
\hline & & & \\
\hline & & & \\
\hline & & & \\
\hline & & & \\
\hline & & & \\
\hline & & & \\
\hline & & & \\
\hline & & & \\
\hline & & & \\
\hline
\end{tabular}

